\title{
Joint Operation of Surface Water and Groundwater Reservoirs to Address Water Conflicts in Arid Regions: An Integrated Modeling Study
}

\author{
Yong Tian ${ }^{1,2}$, Jianzhi Xiong ${ }^{1}$, Xin He ${ }^{1,2,3}$, Xuehui Pi ${ }^{1}$, Shijie Jiang ${ }^{1,4}$, Feng Han ${ }^{1,2}$ and \\ Yi Zheng 1,2,5,* \\ 1 School of Environmental Science and Engineering, Southern University of Science and Technology, \\ Shenzhen 518055, China; tiany@sustc.edu.cn (Y.T.); xiongjz@mail.sustc.edu.cn (J.X.); hex@sustc.edu.cn (X.H.); \\ pixh@mail.sustc.edu.cn (X.P.); jiangsj@mail.sustc.edu.cn (S.J.); hanf@sustc.edu.cn (F.H.) \\ 2 Shenzhen Municipal Engineering Lab of Environmental IoT Technologies, Southern University of Science \\ and Technology, Shenzhen 518055, China \\ 3 Department of Hydrology, Geological Survey of Denmark and Greenland, Copenhagen 1350, Denmark \\ 4 Department of Civil and Environmental Engineering, National University of Singapore, \\ Singapore 117576, Singapore \\ 5 Guangdong Provincial Key Laboratory of Soil and Groundwater Pollution Control, Southern University of \\ Science and Technology, Shenzhen 518055, China \\ * Correspondence: zhengy@sustc.edu.cn; Tel.: +86-755-8801-8030
}

Received: 31 July 2018; Accepted: 17 August 2018; Published: 19 August 2018

\begin{abstract}
At the basin scale, the operation of surface water reservoirs rarely takes groundwater aquifers into consideration, which can also be regarded as reservoirs underground. This study investigates the impact of reservoir operation on the water cycle and evaluates the effect of the joint operation of surface water and groundwater reservoirs on the water conflict in arid regions through an integrated modeling approach. The Heihe River Basin (HRB) in northwestern China is selected as the study area. Our results show that the ecological operational strategies of a reservoir under construction in the upper HRB have a direct impact on the agricultural water uses and consequently affect other hydrological processes. The ecological operation strategy with a smaller water release and a longer duration is beneficial to securing the environmental flow towards the downstream area and to replenishing aquifers. With the joint operation of surface water and groundwater reservoirs, a balance among the agriculture water need, the groundwater sustainability in the Middle HRB and the ecological water need in the Lower HRB can be flexibly achieved. However, the joint operation can hardly improve the three aspects simultaneously. To resolve the water conflict in HRB, additional engineering and/or policy measures are desired.
\end{abstract}

Keywords: reservoir operation; integrated surface water-groundwater model; Heihe River Basin; environmental flow; irrigation

\section{Introduction}

Irrigation plays an indispensable role in agricultural water supply when rainfall is not sufficient to sustain crop growth. Currently, the irrigated cropland produces more than $40 \%$ of the total cereal yield worldwide [1,2]. Globally, about $54 \%$ of the total irrigated area is dependent on surface water (SW) such as rivers, lakes, artificial canals and reservoirs [3]. Meanwhile, in arid and semi-arid regions of the world where surface water is not abundantly available, groundwater (GW) abstraction is often required for irrigation purposes. According to Siebert et al. [4], the total area irrigated by groundwater is nearly 114 million hectares globally. In most arid and semi-arid regions, irrigation with 
groundwater has experienced a considerable increase over the past few decades mainly due to the growing demand for agricultural products and the changing climate [5]. In the North China Plain, one of China's most important agricultural regions, approximately $73 \%$ of the groundwater extraction is used for irrigation [6]. In the United States, around $60 \%$ of the irrigation relies on groundwater, especially in California's Central Valley and the High Plains [7]. Surface water reservoirs are enlarged natural or artificial lakes, storage ponds or impoundments created using a dam or lock to store water. Operating several surface water reservoirs next to each other collectively in order to serve a defined single purpose has become a common practice. A groundwater aquifer, although buried and unseen, can also act as a lumped water storage unit with a known capacity, which resembles a surface water reservoir [8]. Therefore, using groundwater pumping for irrigation can, in principle, be conceptualized as operating surface water reservoirs. Kundzewicz and Döll [9] analyzed the potential of using the natural storage capacity and the buffering effect provided by groundwater reservoirs to cope with highly variable surface water supply in different years. Scanlon et al. [10] further discussed the possibility of utilizing groundwater reservoirs to better adapt to climate extremes in California's Central Valley and central Arizona.

Taking groundwater as a part of the reservoir chain and considering the joint effect of surface water and groundwater reservoirs simultaneously is a relatively new research topic [11]. For instance, Castle et al. [12] assessed the influence of conjunctive surface water and groundwater use on water availability in the Colorado River Basin by estimating the water storage change of both surface water and groundwater reservoirs from satellite images. Fuchs et al. [13] quantified the resilience of the agricultural system that depends on the conjunctive use of surface and groundwater in the Rincon Valley. Nikoo et al. [14] established optimal operation scheduling rules for a reservoir-river-groundwater joint system through data mining. To our knowledge, however, it is rarely reported that both surface water and groundwater reservoirs are operated jointly for water resources conservation via integrated surface water-groundwater modeling.

Increasing demand for irrigation has created human-nature water conflicts and therefore posed many challenges in water resources management. Such a problem is especially serious in arid and semi-arid regions. As an example, the Heihe River Basin (HRB), our study area, has witnessed this conflict gradually developing in the past 30 years. HRB is the second largest endorheic river basin in China and is agriculturally intensive. In the late 1990s, the growing irrigation in the Middle HRB (MHRB) significantly decreased the streamflow available for the Lower HRB (LHRB) and therefore deteriorated the ecological conditions [15-18]. To protect the fragile ecosystems in the Lower HRB, the central government restricted the surface water diversion since 2000 in the Middle HRB [19]. However, the restriction of surface water usage led to a significant increase of groundwater pumping in the Middle HRB, since it was not strictly regulated [20]. Recently, the construction of a new reservoir in the upper HRB basin has been approved, which aims to enhance the water resources management in the basin. However, how the new reservoir may change the water cycle in the middle and Lower HRB has not been systematically investigated by fully accounting for the groundwater reservoir effect, which motivated this study. Therefore, the main objectives of this study are: (1) to quantify the impact of the new reservoir in the upper HRB on the water cycle in the middle and Lower HRB; and (2) to evaluate the effect of the joint operation of surface water and groundwater reservoirs on the water conflict in HRB, based on integrated surface water-groundwater modeling. Overall, this study provides insights into the water resources management in arid regions.

\section{Data and Methods}

\subsection{Study Area}

The Heihe River Basin (HRB) is a typical endorheic river basin in the arid region in the northwest of China. It is located between $97.1^{\circ} \mathrm{E}-102.0^{\circ} \mathrm{E}$ and $37.7^{\circ} \mathrm{N}-42.7^{\circ} \mathrm{N}$. The entire basin can be divided into the upper, middle and lower stream areas, with very different landscapes. The upper stream basin 
is characterized by a mountainous area on the northern margin of the Qinghai-Tibetan Plateau. It is densely vegetated with forests and grasslands. The Middle HRB is dominated by the Gobi Desert, while many irrigated farmlands exist inside the oases. The Lower HRB is mainly a desert with very little vegetation. More than 30 rivers originated in the upstream area bring approximately 3651 million $\mathrm{m}^{3}$ of water per year to the midstream area. The largest stream, namely the Heihe River, has a length of $928 \mathrm{~km}$. It originates from the Qilian Mountains, flows towards the north and ends in a terminal lake, the East Juyan Lake (EJL), in the Gobi Desert. Yingluoxia (YLX) and Zhengyixia (ZYX) are usually regarded as the starting points of the midstream and lower stream of the Heihe River, respectively (see Figure 1). In the upstream, the Heihe River has a major tributary called Babaohe River, which flows into the main stream within the vicinity of the municipality Huangzangsi where the new reservoir is under construction. Daily streamflow measurements are carried out at four gaging stations as indicated by the blue points in Figure 1. Qilan, YLX and ZYX gaging stations are located at the main stream of the Heihe River, and Zhamashike gaging station is located at the Babaohe River. Annual streamflow through Qilian, Zhamashike, YLX and ZYX is 8,204,801,770 and 1010 million $\mathrm{m}^{3}$, respectively.

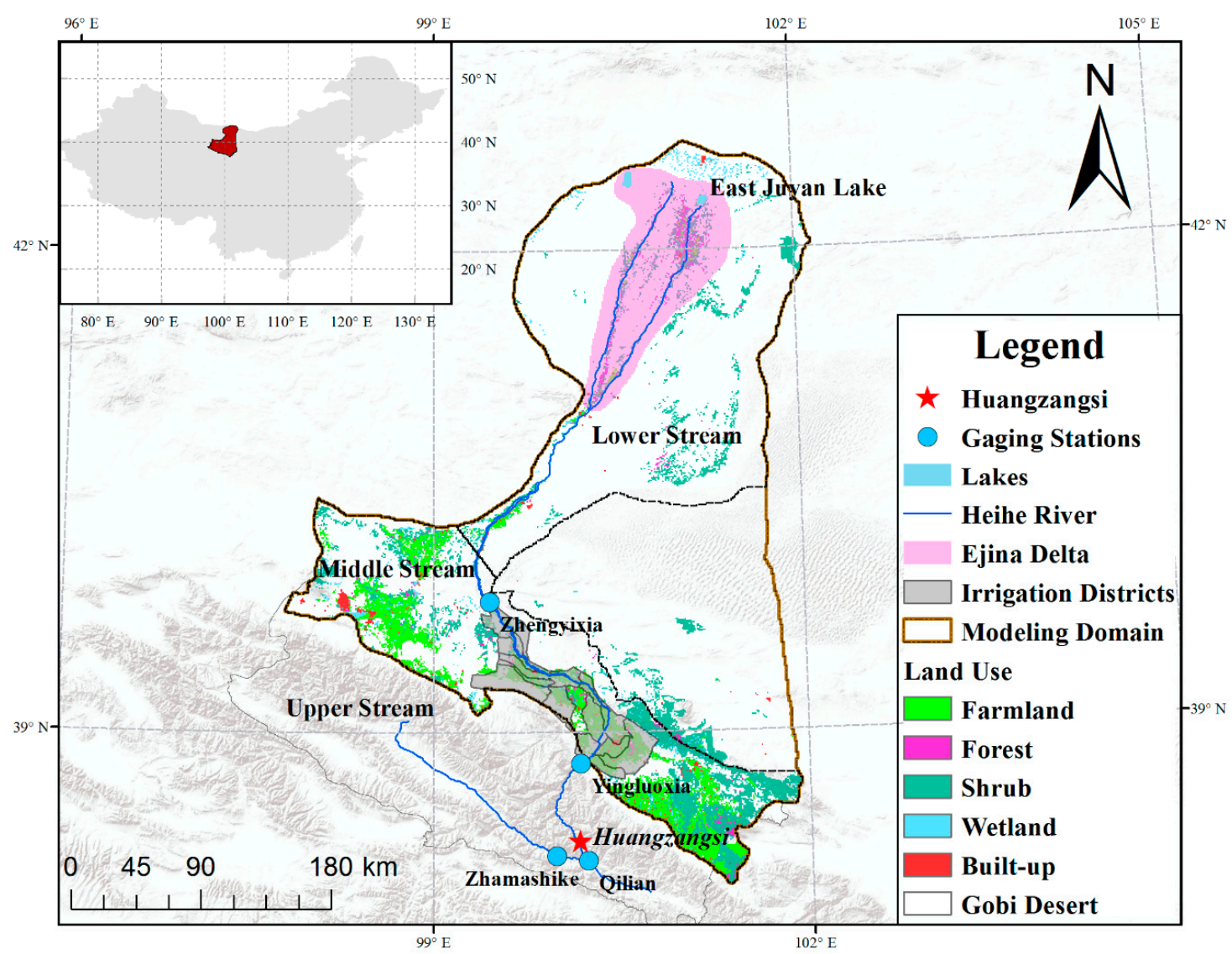

Figure 1. The study area.

In the midstream area, the most common crops are corn and winter wheat. A complicated aqueduct system has been developed in this area. The basic unit for water resources management is called an irrigation district. There are 17 irrigation districts to which stream water from the middle stream of the Heihe River is diverted. Only water consumption from the agricultural sector is considered in these irrigation districts in this study. According to the statistics by the local water resources authority, in 2000-2012, agriculture in the 17 irrigation districts consumed approximately 1860 million $\mathrm{m}^{3}$ of water per year, $80 \%$ of which was diverted from the main Heihe River, and the rest was pumped from the local groundwater aquifer. To secure the environmental flow towards the lower stream under different hydrological conditions, a water allocation plan has been implemented since 
2000. For example, in a normal year (i.e., the annual flow from Yingluoxia reaches 1580 million $\mathrm{m}^{3}$ ), the flow through Zhengyixia should be no less than 950 million $\mathrm{m}^{3}$. Since 2000, diversion of the stream flow has been restricted in the midstream area, which has resulted in a substantial increase of groundwater pumping. In recent years, the groundwater pumping has also been regulated. Thus, the agriculture in the midstream area is now facing a great risk of irrigation water shortage [21]. The water resources authorities have therefore been resorting to hydraulic engineering measures, such as reservoirs, in order to mitigate the water shortage problem in the irrigation districts.

In fact, in the past decades, many surface water reservoirs have been built in the natural low-lying lands along the Heihe River in the midstream area. As of 2012, there were 20 reservoirs with a total water storage of 48.65 million $\mathrm{m}^{3}$. This amount is able to irrigate more than 20,000 ha of farmland. All these reservoirs are replenished by diverting water from the Heihe River, except the one named Shuangquanhu, which is replenished by natural springs. However, the storage capacity of the existing reservoirs is quite small, compared to the irrigation demand. In addition, the loss of water through evaporation is non-negligible, which is approximately 17 million $\mathrm{m}^{3}$ per year, accounting for more than $1 / 3$ of the total reservoir storage. Therefore, as planned, all the plain reservoirs will stop operating in the near future, except the Shuangquanhu Reservoir. Instead, a large reservoir named Huangzangsi is now being built in the upper mountainous area (Figure 1). The total storage of the Huangzangsi Reservoir is approximately eight-times larger than the sum of all the existing plain reservoirs. More information about this reservoir is provided in Section 2.3. It is expected that, with this new reservoir, the irrigation demand in the midstream area can be better met, and the environmental flow towards the lower stream area can be more secured. This provides a unique opportunity to study the joint operation of the surface water and groundwater reservoirs in the HRB in order to alleviate the human-nature water conflict.

\subsection{Hydrological Model}

GSFLOW (Coupled Groundwater and Surface Water Flow Model) (Version 1.1.6, U.S. Geological Survey, Reston, VA, U.S.) is the model applied in the present study. It is an integrated surface water-groundwater model developed by the United States Geological Survey (USGS), which can simulate all the major hydrological processes of the terrestrial water cycle [22]. GSFLOW couples the Precipitation-Runoff Modeling System (PRMS) (Version 3.0.5, U.S. Geological Survey, Reston, VA, U.S.) with the Modular Groundwater Flow Model (MODFLOW-2005) (Version 1.9.1, U.S. Geological Survey, Reston, VA, U.S.) to simulate both the surface water hydrology (top of the plant canopy to the root zone) and the three-dimensional groundwater (the base of the root zone to the base of the aquifers) movement. In the surface water domain, hydrologic response units (HRUs) are the basic computing units, which can be either regular grids or irregular polygons. GSFLOW uses a cascade method to route the overland flow and interflow between HRUs and from HRUs to streams and lakes. The subsurface domain is discretized with finite difference grids. To simulate the two-way interactions between surface water and groundwater, GSFLOW defines a "gravity reservoir" as a storage in which an HRU exchanges water with the MODFLOW grid(s) at places where they intersect. The unsaturated zone is defined as the space between the root zone and the top of the groundwater table, which is computed using the Unsaturated Zone Flow package (UZF1) [23]. Streams and lakes are simulated using the Streamflow Routing package (SFR2) [24] and Lake package [25], respectively. In reaches where the stream water is connected to the groundwater, stream-aquifer exchange is calculated based on the head difference using Darcy's law. More details on GSFLOW can be found in Markstrom et al [22].

Tian et al. [20] improved the capacity of GSFLOW by adding two new irrigation modules, so it simulates agricultural water management activities. One of the modules is to distribute the diverted water from streams to farmlands through an aqueduct system, and the other is to distribute the abstracted groundwater to the farmlands close to the pumping wells. These two modules require daily surface water diversion rate and pumping rate as input. Since it is difficult to obtain these data, we developed a third module, the Water Resources Allocation (WRA) module, for GSFLOW 
recently. Besides integrating functionalities of the two irrigation modules, the WRA module enables one to simulate demand-based diversion and pumping rates. HRUs with farmlands are the basic computing units. The crop type in each HRU and the irrigation quota for each crop need to be predefined. The irrigation quota could be changed from year to year or kept unchanged throughout the entire simulation period. Based on the crop type and irrigation quota, water demand at each HRU is calculated. The demand is supplied by precipitation at first if it rains, then the remaining part is supplied by irrigation. Irrigation in each HRU is assumed to be supplied by either surface water diversion or groundwater pumping, or the combination of the two. The proportions of diversion and pumping in the total irrigation are predefined for each HRU, based on which expected diversion and pumping are first calculated. Then, actual diversion is computed by considering stream routing, and actual pumping is computed by considering the available groundwater in the aquifer. Finally, the actual diversion and pumping is distributed to HRUs by using the method in our previous study [20]. It is noted that the demand for irrigation may not be met $100 \%$, which can be caused by insufficient stream flow or drying of the groundwater wells.

Based on the data availability, the updated GSFLOW model has been applied to the middle and lower streams of HRB over the period 2000-2012 [26]. This period includes wet, dry and normal years and is therefore representative. The model requires daily streamflow at YLX as the boundary conditions. After construction of the Huangzangsi Reservoir, the streamflow at YLX will be greatly changed based on the reservoir's operation, which may lead to significant changes of the water cycle in the middle and lower streams of HRB. Thus, we developed a program to simulate operation of the Huangzangsi Reservoir, which is described in the following section.

\subsection{The Huangzangsi Reservoir}

The Huangzangsi Reservoir under construction is on the upstream of the Heihe River (Figure 2), approximately $70 \mathrm{~km}$ from the Yingluoxia gaging station. It receives the main stream of the Heihe River and the Babaohe River. Table 1 summarizes the physical and hydrological characteristics of the reservoir. The normal storage capacity of the reservoir ranges from 61 million $\mathrm{m}^{3}$ (the dead storage) to 356 million $\mathrm{m}^{3}$ (the normal storage). The water surface covers an area of $11.01 \mathrm{~km}^{2}$ at its normal water level. The Huangzangsi Reservoir is designed to be a multipurpose reservoir, where two main purposes are meeting the agriculture water demand by the Middle HRB and meeting the environmental flow demand by the Lower HRB. It is important to note that the reservoir is not intended to control flooding, thus the normal water level and flood control water level have the same value of $2628 \mathrm{~m}$. The construction of the reservoir is expected to be finished in 2022. All of the reservoir's information was obtained from the environmental impact assessment report provided by the Heihe River Basin Authority [27].

Our study assumes that the Huangzangsi Reservoir is operated based on its rule curves, where the time of decision, the present water level and the overall water demand are the three constraining factors. The overall water demand consists of irrigation water demand in the midstream area, the environmental flow demand in the lower stream area and the minimum base flow demand. Table 2 shows the monthly water demand for the reservoir operation. These values were derived based on statistics and hydrological observations during the period 2000-2012. The irrigation water demand was estimated based on annual statistics by the Water Bureau of the Zhangye City [26]. As Table 2 indicates, irrigation occurs mainly from March-November. The environmental flow demand in the lower stream area was estimated based on the report provided by the Heihe River Basin Authority [27]. The minimum base flow demand occurs from December in the previous year to March, and it is assumed to be $25 \%$ of the reservoir's inflow during these months. 


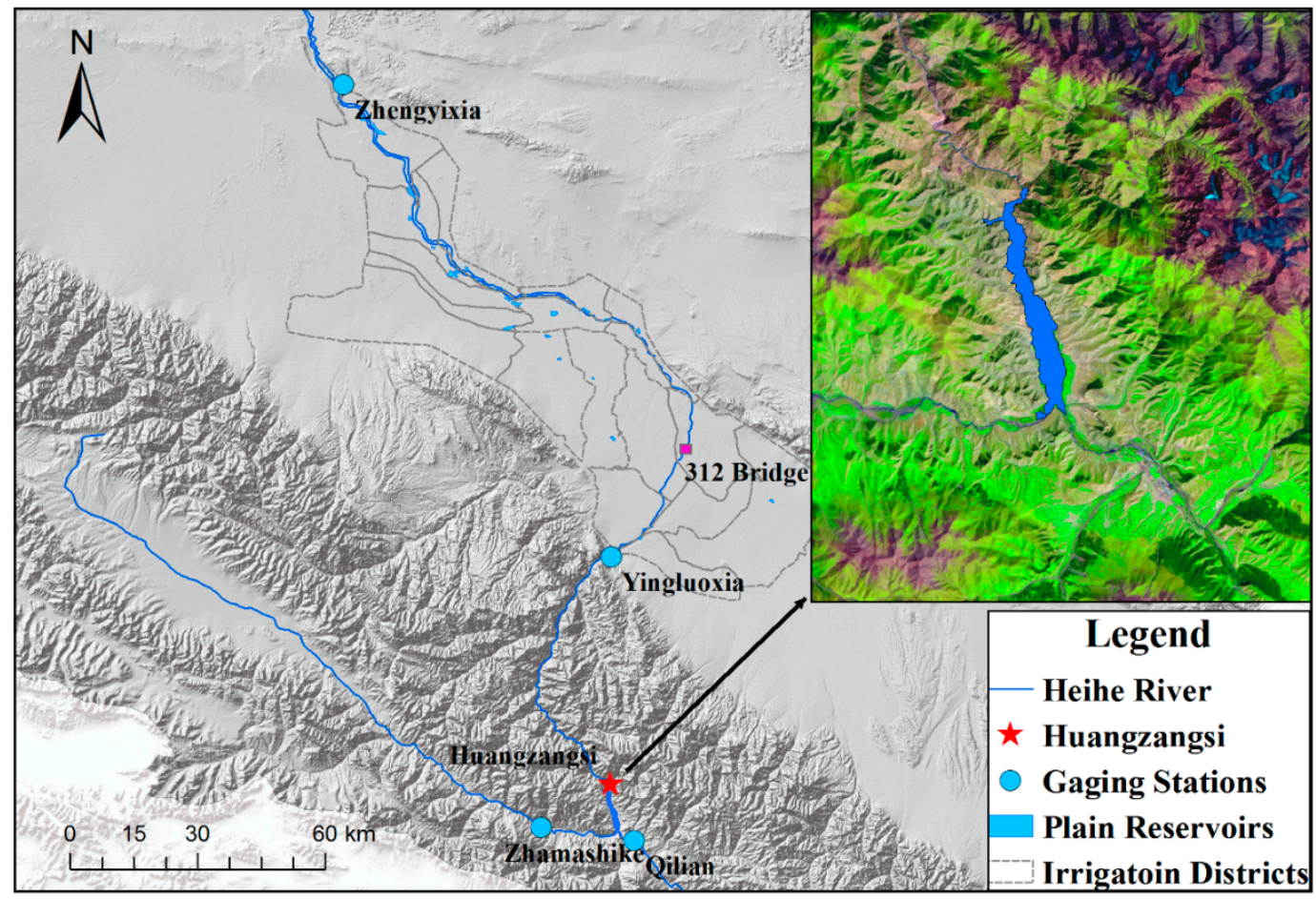

Figure 2. The Huangzangsi Reservoir in the upstream mountainous area and the existing small reservoirs in the plain midstream area.

Table 1. Hydrological and physical characteristics of the Huangzangsi Reservoir.

\begin{tabular}{ll}
\hline Hydrological Characteristics & Value \\
\hline Basin area above dam site & $7648 \mathrm{~km}^{2}$ \\
Annual inflow & $1285 \times 10^{6} \mathrm{~m}^{3}$ \\
Averaged annual discharge & $40.7 \mathrm{~m}^{3} / \mathrm{s}$ \\
Maximum measured discharge & $603 \mathrm{~m}^{3} / \mathrm{s}$ \\
\hline Physical Characteristics & \\
\hline Maximum water level & $2629 \mathrm{~m}$ (elevation) \\
Normal water level & $2628 \mathrm{~m}($ elevation) \\
Flood control water level & $2628 \mathrm{~m}($ elevation) \\
Dead storage level & $2580 \mathrm{~m}(\mathrm{elevation})$ \\
Water surface area at normal water level & $11.01 \mathrm{~km}^{2}$ \\
Length of reservoir at normal level & $13.5 \mathrm{~km}^{6}$ \\
Total storage & $406 \times 10^{6} \mathrm{~m}^{3}$ \\
Dead storage & $61 \times 10^{6} \mathrm{~m}^{3}$ \\
Normal storage & $356 \times 10^{6} \mathrm{~m}^{3}$ \\
Maximum discharge capability & $2775 \mathrm{~m}^{3} / \mathrm{s}$ \\
\hline
\end{tabular}


Table 2. Monthly demands considered for the operation of the Huangzangsi Reservoir.

\begin{tabular}{|c|c|c|c|}
\hline \multirow{2}{*}{ Month } & \multicolumn{3}{|c|}{ Water Demands } \\
\hline & Surface Water for Irrigation $\left(10^{6} \mathrm{~m}^{3}\right)$ & Environmental Flow $\left(10^{6} \mathrm{~m}^{3}\right)$ & Base Flow $\left(10^{6} \mathrm{~m}^{3}\right)$ \\
\hline January & 0 & 0 & 6 \\
\hline February & 0 & 0 & 6 \\
\hline March & 22 & 0 & 9 \\
\hline April & 72 & 140 & 0 \\
\hline May & 183 & 0 & 0 \\
\hline June & 379 & 0 & 0 \\
\hline July & 305 & 82 & 0 \\
\hline August & 344 & 82 & 0 \\
\hline September & 101 & 202 & 0 \\
\hline October & 101 & 0 & 0 \\
\hline November & 219 & 0 & 0 \\
\hline December & 0 & 0 & 9 \\
\hline Total & 1727 & 506 & 30 \\
\hline
\end{tabular}

For the Huangzangsi Reservoir, there are only two basic rule curves, the Normal Curve (NC) and Critical Curve (CC). The values of NC and CC are determined by the normal water level and dead storage level, respectively, and they are kept unchanged throughout a year. The reservoir operates to maintain the water level below NC (2628 m) and above CC (2580 m). Based on the rule curves, there are three distinct operational strategies, which are described in Table 3. To meet the environmental flow demand, a special category of reservoir operation called environmental flow regulation is designed for the study area. Under this operation, the reservoir discharges water within a short period, and meanwhile, the irrigation districts in the Middle HRB are not allowed to divert water from the main Heihe River. This operation is to ensure that enough flow can reach the Lower HRB and replenish the terminal lake. The short period can range from 3 days-20 days, and it is scheduled in the middle of April, July, August and September.

The water balance of the Huangzangsi Reservoir under the abovementioned operation can be written as:

$$
S_{t+1}=S_{t}+Q_{t}-R_{t}-A_{t} e_{t}, \quad \forall t
$$

where $S_{t}$ is storage at the beginning of the period $t ; Q_{t}$ is inflow during the period $t ; R_{t}$ is the water release in the period $t ; A_{t}$ is the water surface area at the beginning of the period $t ; e_{t}$ is evaporation rate during the period $t ; S_{t}, Q_{t}, R_{t}$ are in units of cubic meters; $A_{t}$ is in units of square meters; and $e_{t}$ is in units of meters.

The rule curves and operation strategies are used as constraints during the simulation. First, reservoir storage in any period should not exceed its normal storage and also not be lower than its dead storage:

$$
S_{\text {dead }} \leq S_{t} \leq S_{\text {nomal }}, \quad \forall t
$$

Second, water released in any period should not exceed the reservoir's maximum discharge capability:

$$
0 \leq R_{t} \leq R_{\max }, \quad \forall t
$$

The reservoir's operation is simulated at a daily time step over the period from 2000-2012. The reservoir's daily inflow is obtained by summing daily streamflow measured at Qilian and Zhamashike gaging stations (Figure 2). The evaporation rate at the water surface is estimated by applying a factor of 0.7 to the daily Pan evaporation measured at Qilian station.

When considering the reservoir operation, the streamflow at YLX is calculated as follows:

$$
Q_{t}^{Y L X}=R_{t}+L_{t}, \quad \forall t
$$


where $Q_{t}^{Y L X}$ is streamflow at YLX; $L_{t}$ is lateral flow between the Huangzangsi Reservoir and YLX, and is calculated by subtracting the sum of streamflow at Qilian and Zhamashike from the original streamflow at YLX.

Table 3. The basic operational strategies of the Huangzangsi Reservoir based on the rule curves.

\begin{tabular}{cc}
\hline Condition & Operational Decision \\
\hline If storage level $>$ Normal Curve $(\mathrm{NC})$ & Increase water release to keep storage level $=$ NC. \\
\hline If Critical Curve $(\mathrm{CC})<$ storage level $\leq \mathrm{NC}$ & $\begin{array}{c}\text { Perform environmental flow regulation if required. Regulate } \\
\text { release to meet agriculture water and base flow demands. }\end{array}$ \\
\hline If storage level $\leq \mathrm{CC}$ & Stops release to keep storage level $=\mathrm{CC}$. \\
\hline
\end{tabular}

\subsection{Numerical Modeling Experiments}

The model is run from 2000-2012, in total 13 years, at the daily time scale. The actual simulation during that period of time without the new reservoir is considered as the baseline model. Two series of numerical simulations are designed, namely Series A and Series B, in order to reflect the situation if the new reservoir had existed. Series $A$ is aimed at investigating the impact of the different reservoir operational strategies on the hydrological processes in the middle and Lower HRB, where demand of groundwater pumping is fixed. Series B is used to investigate the relationship between the reservoir's operational strategy and groundwater exploitation practices in the study region. Series A specifies three environmental flow conservation schemes, which are shown in Table 4 as Experiments A1, A2 and A3. The total volume of the water released from the reservoir remains the same for the ecological flow purposes in these three experiments, while the water release for non-ecological flow purposes can still be different from one experiment to another. The duration and discharge rate of each operational strategy varies: Experiment A1 has the shortest duration and the largest discharge rate among the three experiments, while Experiment $\mathrm{A} 3$ has the longest duration and the smallest discharge rate. In general, a higher discharge in a single release may lead to a larger chance for the streamflow to replenish the terminal lake. Hereafter, the strategies in Experiments A1, A2 and A3 are referred to as the ecological operational strategies. For comparison, an additional experiment, Experiment A0, is also performed, in which only the basic operational strategy is applied without considering the ecological flows in the downstream.

Table 4. Operational strategies of the four experiments in Series A.

\begin{tabular}{|c|c|c|c|c|c|c|c|}
\hline A0 & & A1 & & A2 & & A3 & \\
\hline Period & $\begin{array}{l}\text { Discharge } \\
\left(\mathrm{m}^{3} / \mathrm{s}\right)\end{array}$ & Period & $\begin{array}{l}\text { Discharge } \\
\left(\mathrm{m}^{3} / \mathrm{s}\right)\end{array}$ & Period & $\begin{array}{l}\text { Discharge } \\
\left(\mathrm{m}^{3} / \mathrm{s}\right)\end{array}$ & Period & $\begin{array}{l}\text { Discharge } \\
\left(\mathrm{m}^{3} / \mathrm{s}\right)\end{array}$ \\
\hline N/A & N/A & $\begin{array}{l}\text { April 1-5 } \\
\text { July 10-12 } \\
\text { August 10-12 } \\
\text { September 10-15 }\end{array}$ & $\begin{array}{l}324 \\
318 \\
315 \\
390 \\
\end{array}$ & $\begin{array}{l}\text { April 1-10 } \\
\text { July 10-15 } \\
\text { August 10-15 } \\
\text { September 10-21 }\end{array}$ & $\begin{array}{l}162 \\
159 \\
158 \\
195 \\
\end{array}$ & $\begin{array}{l}\text { April 1-15 } \\
\text { July 10-18 } \\
\text { August 10-18 } \\
\text { September 10-27 }\end{array}$ & $\begin{array}{l}108 \\
106 \\
105 \\
130 \\
\end{array}$ \\
\hline N/A & $\mathrm{N} / \mathrm{A}$ & $\begin{array}{l}\text { Duration } \\
\text { Av. Discharge } \\
\text { Total volume }\end{array}$ & $\begin{array}{l}17 \text { days } \\
344.5 \mathrm{~m}^{3} / \mathrm{s} \\
506 \times 10^{6} \mathrm{~m}^{3}\end{array}$ & $\begin{array}{l}\text { Duration } \\
\text { Av. Discharge } \\
\text { Total volume } \\
\end{array}$ & $\begin{array}{l}34 \text { days } \\
172.2 \mathrm{~m}^{3} / \mathrm{s} \\
506 \times 10^{6} \mathrm{~m}^{3}\end{array}$ & $\begin{array}{l}\text { Duration } \\
\text { Av. Discharge } \\
\text { Total volume }\end{array}$ & $\begin{array}{l}51 \text { days } \\
114.8 \mathrm{~m}^{3} / \mathrm{s} \\
506 \times 10^{6} \mathrm{~m}^{3}\end{array}$ \\
\hline
\end{tabular}

Note: Av. is the abbreviation of Average.

Since groundwater recharge plays a critical role in sustaining a healthy ecosystem in the lower stream, it is important to consider the impact of groundwater abstraction together with the reservoir operational strategies. As our previous study [28] revealed, for the Middle HRB, if more groundwater is used in the irrigation districts that are closer to the river and more river water is diverted to the districts that are further away from the river, the water use efficiency for irrigation may be increased. Experiment $B$ is designed to represent this spatial operation of the groundwater reservoir, in which the changes in pumping ratio at different irrigation districts follow the suggestion by Wu et al. [28]. The pumping ratio is defined as the percentage of groundwater in the total irrigation water supply. 
Experiment B considers the ecological operational strategy in Experiment A3 (longest release duration with smallest rate), and it assumes that the irrigation water demand at all the irrigation districts remains unchanged. Essentially, Experiment B represents a joint operation of surface water and groundwater reservoirs in this region.

\section{Results and Discussion}

\subsection{Water Balance of the Reservoir}

The annual averaged water balances for years 2000-2012 at the Huangzangsi Reservoir for Experiments A0-A3 were calculated and are presented in Table 5 . The calculated annual evaporation ranged from $2.9 \times 10^{6}-4.8 \times 10^{6} \mathrm{~m}^{3}$. It is seen that the ecological operational strategies have an obvious impact on the reservoir's water balance. Compared to Experiment A0, Experiments A1-A3 have much higher annual water release and much lower evaporation and storage changes.

Figure 3a demonstrates the intra-annual fluctuation of the annual average water level. All the water levels fluctuated between the normal water level $(2628 \mathrm{~m})$ and the dead storage level $(2580 \mathrm{~m})$. As we can see, without the environmental flow consideration (i.e., in Experiment A0), the effective storage of the reservoir was used twice per year: the first time from December-March in the next year, when no irrigation and environmental flow was requested; therefore, most of the inflow was stored in the reservoir, and the water level gradually increased; and the second time from July-October, when the flood season comes, and the inflow to the reservoir significantly exceeded the water demands for irrigation and ecological flow. The reservoir loses water also twice per year: the first time from April-June, when the water level declines rapidly due to the irrigation demands; and the second time in November, where the water level declines once again due to the irrigation demand for keeping enough soil moisture through winter. The fluctuation of water level in the reservoir was more complicated, since the release of environmental flow could reduce the water level in a very short time period of time. Figure $3 \mathrm{~b}$ illustrates the intra-annual variation of daily evaporation. As can be seen, the ecological operational strategies can substantially reduce the evaporation from the reservoir, especially from April-June and in October.

Table 5. Annual average water balances of the Huangzangsi Reservoir under different operations.

\begin{tabular}{|c|c|c|c|c|c|}
\hline Experiment & $\begin{array}{l}\text { Inflow } Q \\
\left(10^{6} \mathrm{~m}^{3}\right)\end{array}$ & $\begin{array}{l}\text { Water Release }{ }^{R} \\
\quad\left(10^{6} \mathrm{~m}^{3}\right)\end{array}$ & $\begin{array}{l}\text { Evaporation } E \\
\quad\left(10^{6} \mathrm{~m}^{3}\right)\end{array}$ & $\begin{array}{c}\text { Storage Change } \Delta S_{r} \\
\qquad\left(10^{6} \mathrm{~m}^{3}\right)\end{array}$ & $\begin{array}{l}\text { Average Water Level } \\
\text { (Elevation) (m) }\end{array}$ \\
\hline A0 & 1319.1 & 1297.0 & 4.8 & 17.3 & 2604.69 \\
\hline $\mathrm{A} 1$ & 1319.1 & 1311.9 & 2.9 & 4.3 & 2593.09 \\
\hline A2 & 1319.1 & 1311.0 & 3.0 & 5.1 & 2593.89 \\
\hline A3 & 1319.1 & 1308.9 & 3.2 & 7.0 & 2594.45 \\
\hline
\end{tabular}




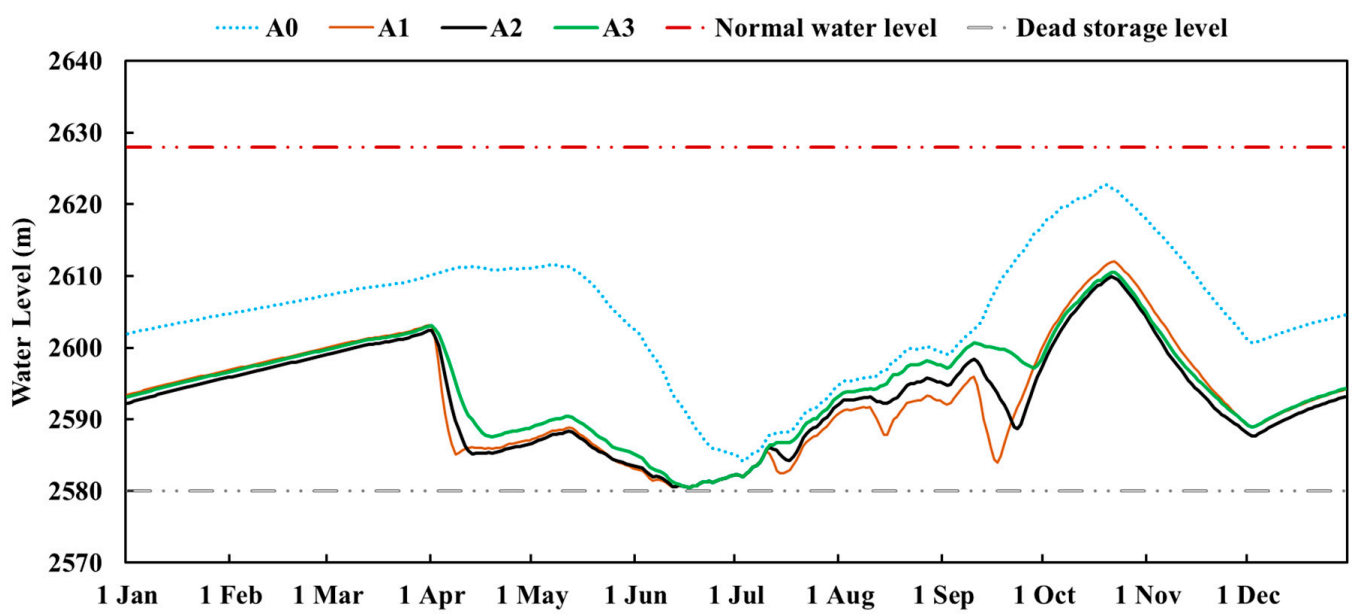

(a)

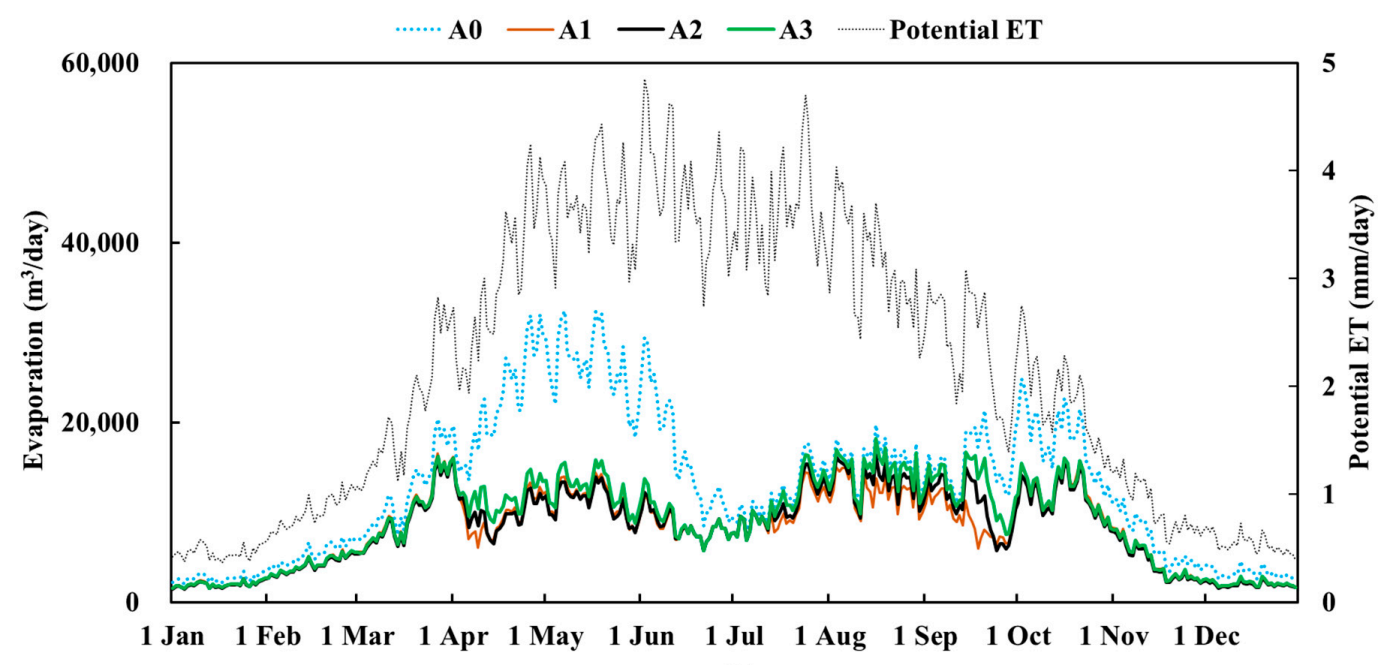

(b)

Figure 3. Impacts of the ecological operations on the water balance of the reservoir on a multiyear average basis. (a) The daily water level; and (b) the daily evaporation from the reservoir.

\subsection{Water Balance at the Middle and Lower HRB}

Inflow of stream water to our model domain at Yingluoxia (YLX) was derived, following the approach introduced in Section 2.3. A set of variables was examined to evaluate the impact of the ecological operational strategies on the hydrological processes in the middle and Lower HRB systematically. Table 6 summarizes the simulation results of selected variables, which represent five key processes including agricultural water uses, streamflow, stream-aquifer interaction, groundwater flow and evapotranspiration. 
Table 6. Key hydrological variables simulated by the Groundwater and Surface Water Flow (GSFLOW) model under different ecological operational strategies. GW, groundwater; MHRB, Middle HRB; ZYX, Zhengyixia; EJL, East Juyan Lake; YLX, Yingluoxia; LHRB, Lower HRB.

\begin{tabular}{|c|c|c|c|c|c|c|}
\hline \multirow{2}{*}{$\begin{array}{c}\text { Hydrological } \\
\text { Process }\end{array}$} & \multirow{2}{*}{ Variable } & \multirow{2}{*}{$\begin{array}{l}\text { Baseline } \\
\text { Scenario }\end{array}$} & \multicolumn{4}{|c|}{ Ecological Operations (Experiment ID) } \\
\hline & & & A0 & A1 & A2 & A3 \\
\hline \multirow{4}{*}{$\begin{array}{l}\text { Agricultural } \\
\text { water uses }\end{array}$} & SW diversion in MHRB $\left(10^{6} \mathrm{~m}^{3}\right)$ & 1456 & 1672 & 1483 & 1402 & 1336 \\
\hline & GW pumping in MHRB $\left(10^{6} \mathrm{~m}^{3}\right)$ & 403 & 405 & 405 & 405 & 405 \\
\hline & Total supply in MHRB $\left(10^{6} \mathrm{~m}^{3}\right)$ & 1859 & 2078 & 1888 & 1807 & 1741 \\
\hline & Degree of demand fulfillment (\%) & 87.39 & 97.67 & 88.76 & 84.97 & 81.85 \\
\hline \multirow{2}{*}{ Streamflow } & Streamflow through ZYX $\left(10^{6} \mathrm{~m}^{3}\right)$ & 994 & 807 & 972 & 1030 & 1079 \\
\hline & Streamflow entering EJL $\left(10^{6} \mathrm{~m}^{3}\right)$ & 74 & 33 & 61 & 68 & 74 \\
\hline \multirow{3}{*}{$\begin{array}{l}\text { Stream-aquifer } \\
\text { interaction }\end{array}$} & Stream leakage in YLX-312B $\left(10^{6} \mathrm{~m}^{3}\right)$ & 466 & 480 & 459 & 466 & 476 \\
\hline & GW discharge in 312B-ZYX $\left(10^{6} \mathrm{~m}^{3}\right)$ & -462 & -484 & -468 & -461 & -455 \\
\hline & Stream leakage in ZYX-EJL $\left(10^{6} \mathrm{~m}^{3}\right)$ & 543 & 518 & 553 & 569 & 583 \\
\hline \multirow{4}{*}{$\begin{array}{l}\text { Groundwater } \\
\text { flow }\end{array}$} & Areal recharge in MHRB $\left(10^{6} \mathrm{~m}^{3}\right)$ & 462 & 461 & 462 & 400 & 389 \\
\hline & Areal recharge in LHRB $\left(10^{6} \mathrm{~m}^{3}\right)$ & 6 & 6 & 6 & 9 & 10 \\
\hline & $\Delta \mathrm{S}$ in MHRB $\left(10^{6} \mathrm{~m}^{3}\right)$ & -86 & -64 & -81 & -84 & -86 \\
\hline & $\Delta \mathrm{S}$ in $\operatorname{LHRB}\left(10^{6} \mathrm{~m}^{3}\right)$ & 15 & 6 & 11 & 14 & 16 \\
\hline \multirow{2}{*}{ Evapotranspiration } & ET in MHRB $\left(10^{6} \mathrm{~m}^{3}\right)$ & 1473 & 1566 & 1564 & 1458 & 1433 \\
\hline & ET in LHRB $\left(10^{6} \mathrm{~m}^{3}\right)$ & 1038 & 859 & 858 & 1055 & 1090 \\
\hline
\end{tabular}

Note: $\Delta S$ is storage change in the saturated zone; a negative value indicates loss of water with respect to initial storage, and a positive value indicates gain of water with respect to initial storage.

The ecological operational strategies have a direct impact on the agricultural water uses, which consequently affect other hydrological processes. Under the baseline conditions (i.e., the baseline scenario), $87.39 \%$ of the total irrigation water demand in the Middle HRB (MHRB) is fulfilled. This percentage could be increased to as high as $97.67 \%$ by employing the function of the new reservoir if the environmental flow is not considered (i.e., Experiment A0). If the environmental flow is taken into consideration (i.e., Experiments A1-A3), more water is needed at the Lower HRB (LHRB), but the degree of demand fulfillment in MHRB would be reduced. For example, in Experiment A3, the annual streamflow through Zhengyixia (ZYX) reaches the maximum value (1079 million $\left.\mathrm{m}^{3}\right)$, but the degree of demand fulfillment $(81.85 \%)$ is the lowest. Figure 4 shows the spatial patterns of the degree of demand fulfillment in the four experiments. It can be seen that the degree of fulfillment decreases in all districts from Experiment A0-Experiment A3.

The streamflow through ZYX is the environmental flow for the Lower HRB, which largely determines how much water can eventually enter the East Juyan Lake (EJL). According to the water allocation plan, the streamflow through ZYX should be 1150 million $\mathrm{m}^{3}$ per year on average in 2000-2012. However, the simulated actual flow (i.e., in the baseline scenario) did not exceed 1000 million $\mathrm{m}^{3}$ per year, and the goal of the water allocation plan was not achieved. As Table 6 indicates, the operations in Experiments A1-A3 push the environmental flow towards the goal, and the flow in Experiment A3 is very close to the goal. This suggests that a smaller water release with a longer duration is beneficial to achieve the water allocation goal.

As for stream-aquifer interaction, based on our previous study [26], three distinctive segments along the main river can be identified as either gaining or losing streams. YLX to the bridge named 312 Bridge (312B) is a losing segment, where a large amount of streamflow percolates through a thick vadose zone and recharges the aquifer. $312 \mathrm{~B}$ to $\mathrm{ZYX}$ is a gaining segment as a whole, where the aquifer discharges water to the river. $\mathrm{ZYX}$ to the terminal lake (EJL) is another losing segment. Based on our prior understanding, the flux of water in each of the three segments due to stream-aquifer interaction are calculated. It is noted that even though small spatial-temporal variations can happen so that a sub-segment of the gain branch can turn to a losing branch for a short period of time, the multi-annual statistics show that the separations of the three segments do not change from year to year. That is, a smaller water release rate with a longer duration in the ecological operations is beneficial to the replenishment of the aquifer in the mid- and lower stream basins, especially in the lower stream 
segment. In addition, the amount of groundwater discharging to the gaining segment from 312B to ZYX decreases from Experiment A0-Experiment A3.
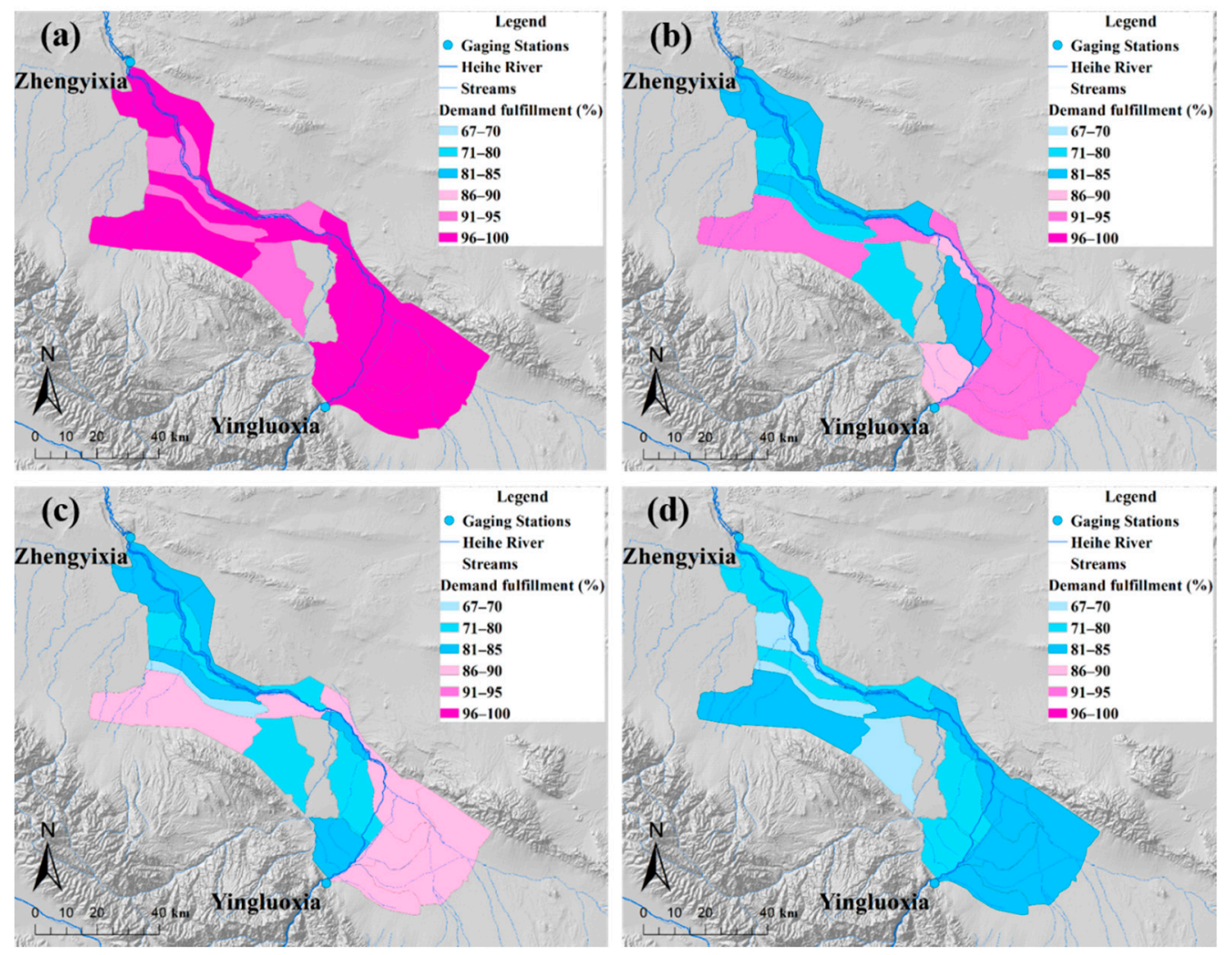

Figure 4. The simulated degree of demand fulfillment under different operations of the Huangzangsi Reservoir. (a-d) correspond to Experiments A0-A3.

In the Middle $\mathrm{HRB}$, groundwater recharge takes place mainly due to the percolation of irrigated water. Thus, when the irrigation is reduced (as seen from Experiment A1-Experiment A3), the groundwater recharge decreases accordingly. As seen in Table 6, even though there is still a negative change in the groundwater storage, the speed of decline is slower from Experiment A3-Experiment A1. This is because of the reduced groundwater recharge. Furthermore, our results suggest that the groundwater storage in the Lower HRB is recovered due to increased stream leakage in the ZYX-EJL segment from Experiments A1-A3.

Evapotranspiration (ET) in the study area largely depends on the availability of surface water. From Experiment A1-A3, when the water supply for irrigation decreases, the ET in the Middle HRB decreases accordingly. On the contrary, the simulated ET in the Lower HRB is higher in Experiment A3 than the other two experiments because more environmental flow is available in the Lower HRB for $A 3$, and thus more surface water is available. Figure 5 demonstrates the spatial pattern of annual average ET in the lower HRB. 

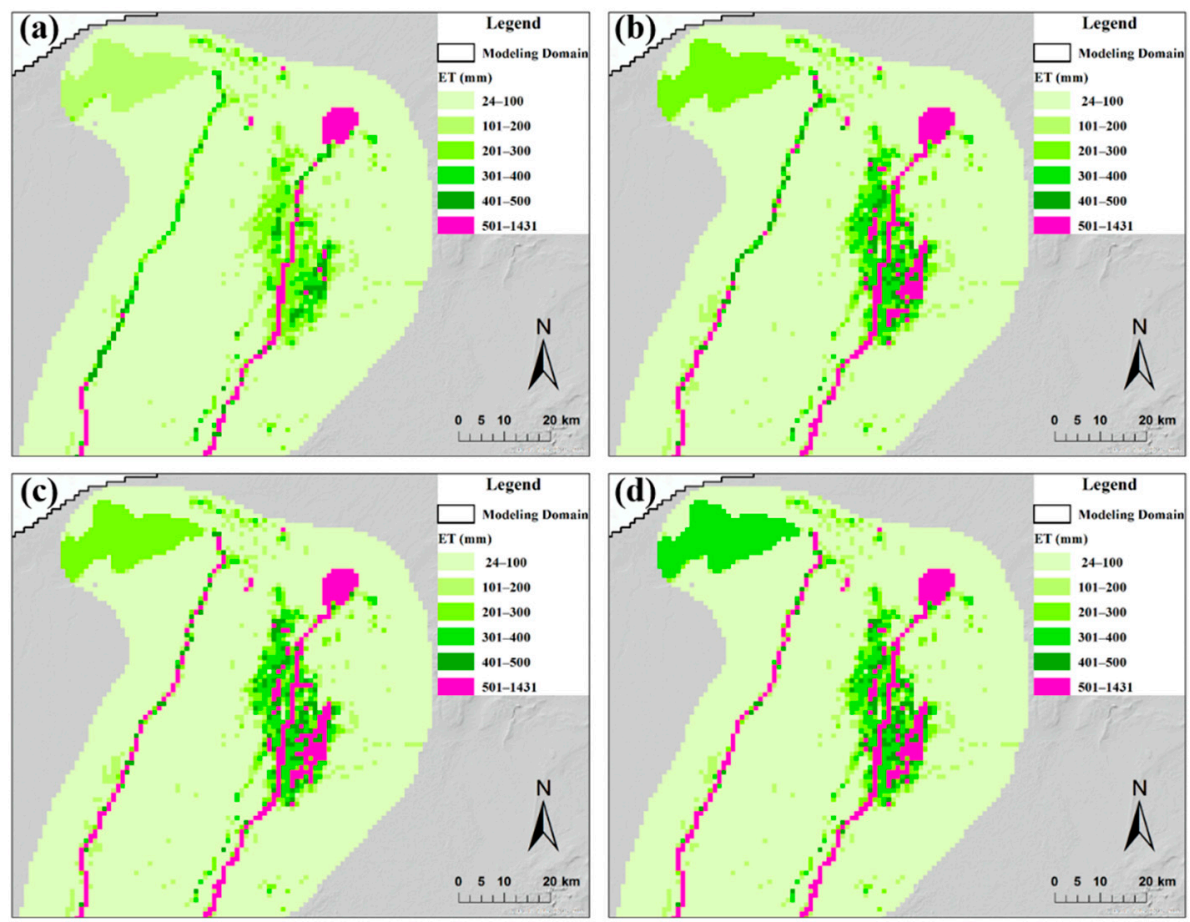

Figure 5. Spatial patterns of annual average Evapotranspiration (ET) in the lower stream under (a) Experiment A0, (b) Experiment A1, (c) Experiment A2 and (d) Experiment A3.

\subsection{Impacts of the Joint Operation}

Several key hydrological variables are selected to investigate the impact of the joint operation in Experiment B. While the overall degree of demand fulfillment is similar in Experiments A3 and B (see Table 7), the spatial pattern of the degree varies. Figure $6 a, b$ show the spatial pattern of the pumping ratio in the 17 irrigation districts in Experiments A3 and B, respectively. Figure $6 \mathrm{c}$ and $6 \mathrm{~d}$ show the change in pumping ratio and the changes in the degree of demand fulfillment. It can be seen that, in the irrigation districts with IDs of 14, 15, 16 and 25 (red areas), the irrigation demand is better met in Experiment B. In contrast, in the irrigation districts with IDs of 23, 30 and 31, the irrigation demand is less met in Experiment B.

Table 7. Key hydrological variables simulated by the GSFLOW model under Experiments A3 and B.

\begin{tabular}{cccc}
\hline Variable & A3 & B & Difference (Percentage Change) \\
\hline SW diversion in MHRB $\left(10^{6} \mathrm{~m}^{3}\right)$ & 1336 & 1307 & $-0.29(-2.14 \%)$ \\
GW pumping in MHRB $\left(10^{6} \mathrm{~m}^{3}\right)$ & 405 & 409 & $0.04(0.79 \%)$ \\
Total supply in MHRB $\left(10^{6} \mathrm{~m}^{3}\right)$ & 1741 & 1716 & $-0.25(-1.45 \%)$ \\
Degree of demand fulfillment $(\%)$ & 81.85 & 80.66 & $-1.19(-1.45 \%)$ \\
Streamflow through ZYX $\left(10^{6} \mathrm{~m}^{3}\right)$ & 1079 & 1031 & $-0.48(-4.49 \%)$ \\
Stream leakage in YLX-312B $\left(10^{6} \mathrm{~m}^{3}\right)$ & 476 & 458 & $-0.18(-3.82 \%)$ \\
GW discharge in 312B-ZYX $\left(10^{6} \mathrm{~m}^{3}\right)$ & -455 & -384 & $-0.71(-15.59 \%)$ \\
Areal recharge in MHRB $\left(10^{6} \mathrm{~m}^{3}\right)$ & 389 & 388 & $-0.01(-0.39 \%)$ \\
Areal recharge in LHRB $\left(10^{6} \mathrm{~m}^{3}\right)$ & 10 & 9 & $-0.01(-6.97 \%)$ \\
$\Delta$ S in MHRB $\left(10^{6} \mathrm{~m}^{3}\right)$ & -86 & -39 & $0.47(54.40 \%)$ \\
$\Delta$ S in LHRB $\left(10^{6} \mathrm{~m}^{3}\right)$ & 16 & 13 & $-0.03(-22.31 \%)$ \\
\hline
\end{tabular}

Note: $\Delta \mathrm{S}$ is storage change in the saturated zone; a negative value indicates loss of water with respect to initial storage, and a positive value indicates gain of water with respect to initial storage. 

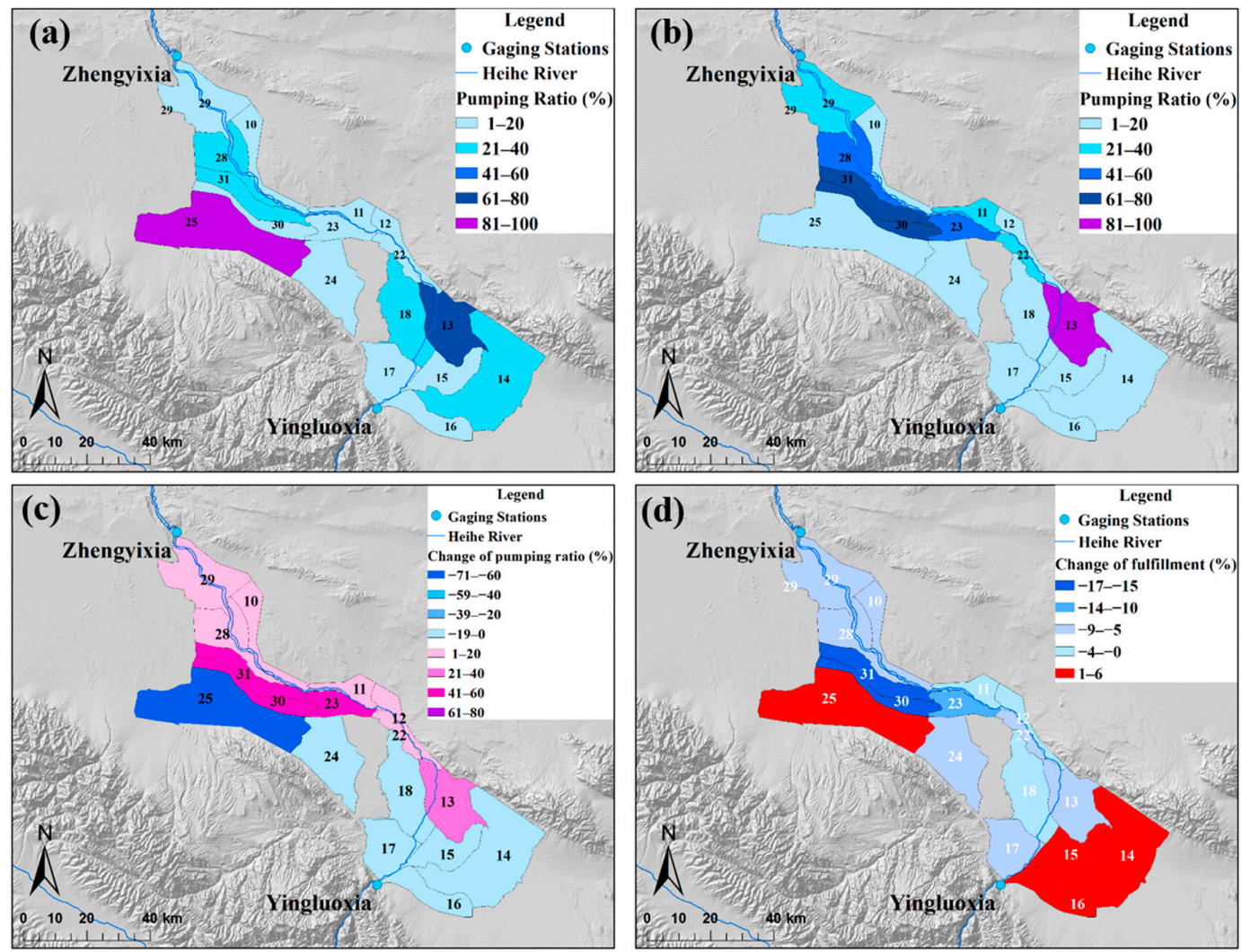

Figure 6. Spatial patterns of the pumping ratios in the 17 irrigation districts. (a) The actual pumping ratios over the period 2000-2012 in Experiment A3; (b) the assumed pumping ratios in Experiment B; (c) changes in the ratios from Experiment A3-B; and (d) changes in the degree of irrigation demand fulfillment. The pumping ratio is defined as the percentage of groundwater in the total irrigation water supply.

As Table 7 indicates, the change in pumping ratio changes the surface water-groundwater interactions, which in turn alters the spatial pattern of the degree of fulfillment. Figure 7 compares spatial patterns of annual average Groundwater (GW) recharge at the 17 irrigation districts. It can be seen that the GW recharge decreases in the districts that are near the river and increases in the districts that are far from the river, while the change of the total areal GW recharge is small. Overall, the decline in groundwater storage in HRB can be significantly slowed down (see $\triangle S$ in MHRB in Table 7). However, this recovery is at the cost of reduced environmental flow through ZYX (see streamflow through ZYX in Table 7). 

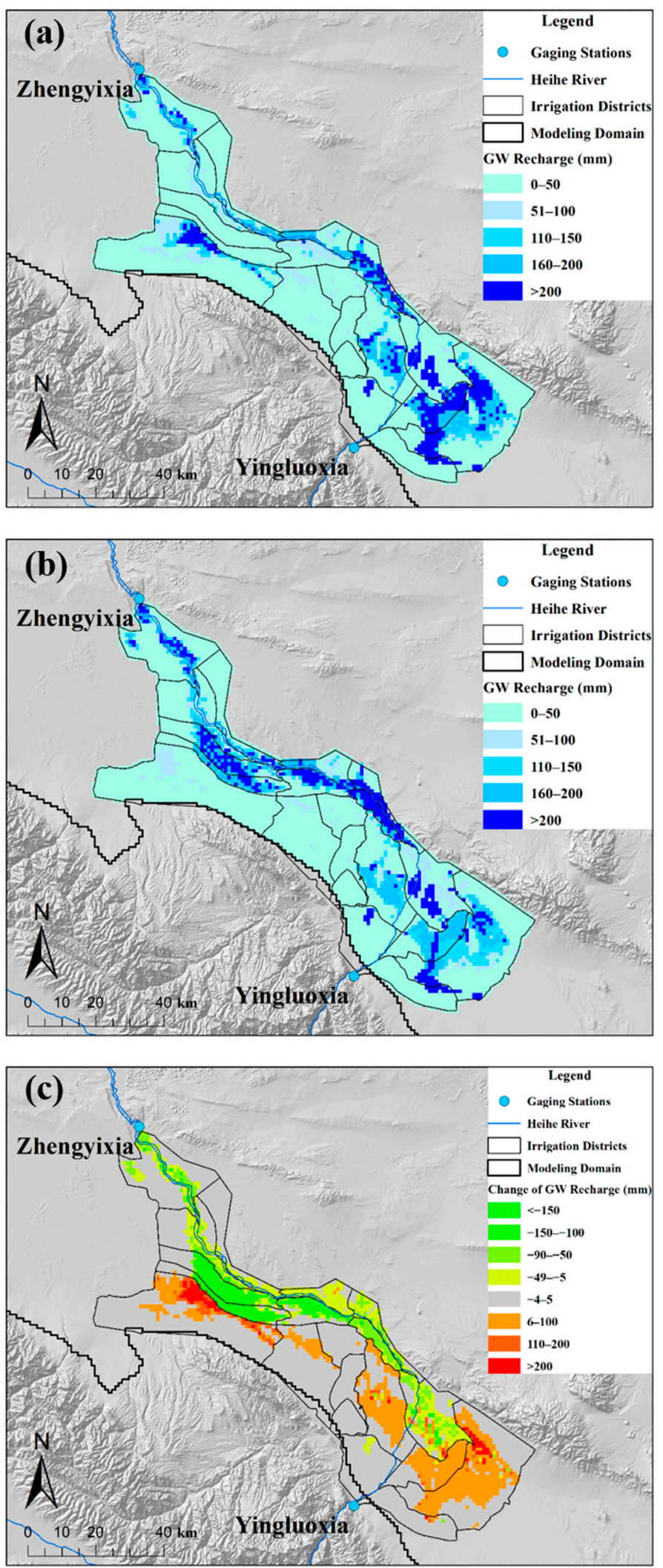

Figure 7. Spatial patterns of annual average Groundwater $(G W)$ recharge at the 17 irrigation districts. (a) The annual average GW recharge in Experiment A3; (b) the annual average GW recharge in Experiment B; and (c) the change in GW recharge from Experiment B-Experiment A3. 
Overall, as suggested by Table 7 and Figure 7, the groundwater operation can enhance the flexibility of the water resources management. With the joint operation of surface water and groundwater reservoir, a balance among the agriculture water need, the groundwater sustainability in the Middle HRB and the ecological water need in the Lower HRB can be easily achieved. For example, if the primary goal of the water resources management is to maintain the sustainability of groundwater in the Middle HRB, the groundwater pumping may consider the spatial pattern in Experiment $B$ (Figure 6b). If the primary goal is to meet the ecological water need of the Lower HRB, the groundwater pumping may consider the spatial pattern in Experiment A3 (Figure 6a). However, the joint operation can hardly improve the three aspects simultaneously. To resolve the water conflict in HRB, further engineering and/or policy measures are desired, besides the reservoir development and groundwater regulation. Water-saving irrigation technologies and reducing the weight of agriculture in the regional economy are potential solutions.

\section{Conclusions}

This study investigates the hydrological impacts of joint operation of surface water and groundwater reservoirs in Heihe River Basin (HRB), using an integrated surface water-groundwater modeling coupled with a reservoir operation simulation model. The integrated model can simulate demand-based diversion and pumping rates, which is specifically designed for arid regions with significant agricultural irrigation. The reservoir operation model evaluates basic and ecological operational strategies. Through a set of numerical experiments, this study further addresses whether and how the joint operation could alleviate the human-water conflict in HRB.

The major findings are summarized as follows. First, based on simulation results of the reservoir operation model, the effective storage of the Huangzangsi reservoir is used twice per year, and the ecological operational strategies can substantially reduce the evaporation from the reservoir. Second, the ecological operational strategies have a direct impact on the agricultural water uses in the Middle HRB, and consequently affect other hydrological processes in the middle and Lower HRB. The ecological operation strategy that has a smaller water release with a longer duration is beneficial to achieve the water allocation goal and to the replenishment of the aquifer in the middle and Lower HRB, but such a strategy may reduce the chance to meet the agriculture water demand of the Middle HRB. Finally, with the joint operation of the surface water and groundwater reservoir, a balance among the agriculture water need, the groundwater sustainability in the Middle HRB and the ecological water need in the Lower HRB can be easily achieved. However, the joint operation can hardly improve the three aspects simultaneously. To resolve the water conflict in HRB, further engineering and/or policy measures are desired, besides the reservoir development and groundwater regulation.

Overall, our study provides insights into the water resources management in arid regions. The study results imply that reservoir operation alone, even considering both surface water and groundwater, may not be sufficient to resolve the typical human-water conflict. Future studies can investigate more management and policy measures, such as using water-saving irrigation technologies and reducing the weight of agriculture in the regional economy.

Author Contributions: Conceptualization, Y.Z. and Y.T. Methodology, Y.T., J.X., X.P. and F.H. Formal analysis, Y.T. Data curation, Y.T. and J.X. Writing, original draft preparation, Y.T. and S.J. Writing, review and editing, Y.Z. and X.H. Supervision, Y.Z. Project administration, Y.Z. Funding acquisition, Y.Z. and Y.T.

Funding: This work was funded by the National Natural Science Foundation of China (No. 41501024; No. 91647201; No. 41622111). Additional support was provided by the Southern University of Science and Technology (No. G01296001) and the Guangdong Provincial Key Laboratory of Soil and Groundwater Pollution Control (No. 2017B030301012).

Acknowledgments: The data used in this study, if not collected by the authors or acknowledged in the text, were provided by the Heihe Program Data Management Center (http:/ / www.heihedata.org).

Conflicts of Interest: The authors declare no conflict of interest. 


\section{References}

1. Doll, P.; Siebert, S. Global modeling of irrigation water requirements. Water Resour. Res. 2002, 38, 8-1-8-10. [CrossRef]

2. Jagermeyr, J.; Gerten, D.; Heinke, J.; Schaphoff, S.; Kummu, M.; Lucht, W. Water savings potentials of irrigation systems: Global simulation of processes and linkages. Hydrol. Earth Syst. Sc. 2015, 19, 3073-3091. [CrossRef]

3. Thenkabail, P.S.; Biradar, C.M.; Noojipady, P.; Dheeravath, V.; Li, Y.J.; Velpuri, M.; Gumma, M.; Gangalakunta, O.R.P.; Turral, H.; Cai, X.L.; et al. Global irrigated area map (GIAM), derived from remote sensing, for the end of the last millennium. Int. J. Remote Sens. 2009, 30, 3679-3733. [CrossRef]

4. Siebert, S.; Burke, J.; Faures, J.M.; Frenken, K.; Hoogeveen, J.; Doll, P.; Portmann, F.T. Groundwater use for irrigation-A global inventory. Hydrol. Earth Syst. Sci. 2010, 14, 1863-1880. [CrossRef]

5. Garrido, A.; Martinez-Santos, P.; Llamas, M.R. Groundwater irrigation and its implications for water policy in semiarid countries: The spanish experience. Hydrogeol. J. 2006, 14, 340-349. [CrossRef]

6. Hu, X.L.; Shi, L.S.; Zeng, J.C.; Yang, J.Z.; Zha, Y.Y.; Yao, Y.J.; Cao, G.L. Estimation of actual irrigation amount and its impact on groundwater depletion: A case study in the Hebei plain, China. J. Hydrol. 2016, 543, 433-449. [CrossRef]

7. Leng, G.Y.; Huang, M.Y.; Tang, Q.H.; Gao, H.L.; Leung, L.R. Modeling the effects of groundwater-fed irrigation on terrestrial hydrology over the conterminous united states. J. Hydrometeorol. 2014, 15, 957-972. [CrossRef]

8. Velazquez, M.P.; Jenkins, M.W.; Lund, J.R. Economic values for conjunctive use and water banking in southern California. Water Resour. Res. 2004, 40. [CrossRef]

9. Kundzewicz, Z.W.; Doll, P. Will groundwater ease freshwater stress under climate change? Hydrolog. Sci. J. 2009, 54, 665-675. [CrossRef]

10. Scanlon, B.R.; Reedy, R.C.; Faunt, C.C.; Pool, D.; Uhlman, K. Enhancing drought resilience with conjunctive use and managed aquifer recharge in California and Arizona. Environ. Res. Lett. 2016, 11. [CrossRef]

11. Murray-Darling Basin Commission (MDBC). Groundwater: A Resource for the Future. Available online: https://www.mdba.gov.au/sites/default/files/archived/mdbc-GWreports/2173_GW_a_resource_ for_the_future.pdf (accessed on 12 August 2018).

12. Castle, S.L.; Thomas, B.F.; Reager, J.T.; Rodell, M.; Swenson, S.C.; Famiglietti, J.S. Groundwater depletion during drought threatens future water security of the Colorado River Basin. Geophys. Res. Lett. 2014, 41, 5904-5911. [CrossRef] [PubMed]

13. Fuchs, E.H.; Carroll, K.C.; King, J.P. Quantifying groundwater resilience through conjunctive use for irrigated agriculture in a constrained aquifer system. J. Hydrol. 2018. [CrossRef]

14. Nikoo, M.R.; Karimi, A.; Kerachian, R.; Poorsepahy-Samian, H.; Daneshmand, F. Rules for optimal operation of reservoir-river-groundwater systems considering water quality targets: Application of M5P model. Water Resour. Manag. 2013, 27, 2771-2784. [CrossRef]

15. Li, X.; Cheng, G.; Ge, Y.; Li, H.; Han, F.; Hu, X.; Tian, W.; Tian, Y.; Pan, X.; Nian, Y.; et al. Hydrological cycle in the heihe river basin and its implication for water resource management in endorheic basins. J. Geophys. Res. Atmos. 2018, 123, 890-914. [CrossRef]

16. Gao, G.; Shen, Q.; Zhang, Y.; Pan, N.; Ma, Y.; Jiang, X.; Fu, B. Determining spatio-temporal variations of ecological water consumption by natural oases for sustainable water resources allocation in a hyper-arid endorheic basin. J. Clean Prod. 2018, 185, 1-13. [CrossRef]

17. Li, Z.; Liu, W.Z.; Zhang, X.C.; Zheng, F.L. Impacts of land use change and climate variability on hydrology in an agricultural catchment on the loess plateau of China. J. Hydrol. 2009, 377, 35-42. [CrossRef]

18. Chen, Y.; Zhang, D.; Sun, Y.; Liu, X.; Wang, N.; Savenije, H.H.G. Water demand management: A case study of the Heihe River Basin in China. Phys. Chem. Earth Parts A/B/C 2005, 30, 408-419. [CrossRef]

19. Wu, X.; Zheng, Y.; Wu, B.; Tian, Y.; Han, F.; Zheng, C.M. Optimizing conjunctive use of surface water and groundwater for irrigation to address human-nature water conflicts: A surrogate modeling approach. Agric. Water Manag. 2016, 163, 380-392. [CrossRef]

20. Tian, Y.; Zheng, Y.; Wu, B.; Wu, X.; Liu, J.; Zheng, C.M. Modeling surface water-groundwater interaction in arid and semi-arid regions with intensive agriculture. Environ. Modell. Softw. 2015, 63, 170-184. [CrossRef] 
21. Wang, Y.; Xiao, H.L.; Lu, M.F. Analysis of water consumption using a regional input-output model: Model development and application to Zhangye City, Northwestern China. J. Arid Environ. 2009, 73, 894-900. [CrossRef]

22. Markstrom, S.L.; Niswonger, R.G.; Regan, R.S.; Prudic, D.E.; Barlow, P.M. Gsflow—Coupled Groundewater and Surfaceewater Flow Model Based on the Integration of the Precipitation-Runoff Modeling System (prms) and the Modular Groundewater Flow Model (modflow-2005); USGS: Reston, VA, USA, 2008; p. 240.

23. Niswonger, R.G.; Prudic, D.E.; Regan, R.S. Documentation of the Unsaturated-Zone Flow (UZF1) Package for Modeling Unsaturated flow Between the Land Surface and the Water Table with Modflow-2005; USGS: Reston, VA, USA, 2006; p. 62.

24. Niswonger, R.G.; Prudic, D.E. Documentation of the Streamflow-Routing (SFR2) Package to Include Unsaturated Flow Beneath Streams-A Modification to SFR1; USGS: Reston, VA, USA, 2005.

25. Merritt, M.L.; Konikow, L.F. Documentation of a Computer Program to Simulate Lake-Aquifer Interaction Using the Modflow Ground Water Flow Model and the MOC3D Solute-Transport Model; USGS: Reston, VA, USA, 2000.

26. Tian, Y.; Zheng, Y.; Zheng, C.M.; Xiao, H.L.; Fan, W.J.; Zou, S.B.; Wu, B.; Yao, Y.Y.; Zhang, A.J.; Liu, J. Exploring scale-dependent ecohydrological responses in a large endorheic river basin through integrated surface water-groundwater modeling. Water Resour. Res. 2015, 51, 4065-4085. [CrossRef]

27. Heihe River Basin Authority. Environmental impact assessment report for the Huangzangsi Reservoir on the Heihe River. Available online: http://www.zhb.gov.cn/gkml/hbb/spwj1/201507/t20150717_306844.htm (accessed on 15 July 2018).

28. Wu, B.; Zheng, Y.; Wu, X.; Tian, Y.; Han, F.; Liu, J.; Zheng, C.M. Optimizing water resources management in large river basins with integrated surface water-groundwater modeling: A surrogate-based approach. Water Resour. Res. 2015, 51, 2153-2173. [CrossRef]

(C) 2018 by the authors. Licensee MDPI, Basel, Switzerland. This article is an open access article distributed under the terms and conditions of the Creative Commons Attribution (CC BY) license (http://creativecommons.org/licenses/by/4.0/). 